Note

\section{Partial Purification and Some Properties of Mitomycin C Inactivating Factors of Pseudomonas convexa 4-87}

\author{
Yasuji Minoda, Hisashi Yamagata, \\ and Tohru Kodama \\ Department of Agricultural Chemistry, \\ The University of Tokyo, \\ 1-1-1 Yayoi, Bunkyo-ku, \\ Tokyo 113, Japan
}

Received October 5, 1987

The development of short-term mutagenicity tests has aided the remarkable progress in screening chemical and natural mutagens and carcinogens from our environment. In the course of detecting mutagens, some factors which suppressed mutagenicity were discovered ${ }^{1,2)}$

In the past decade, many more desmutagens have been found, most of which were of chemical and plant origins. Their modes of action have been thoroughly investigated. We have screened desmutagenic factors against such mutagens as mitomycin $\mathrm{C}(\mathrm{MMC})$, sterigmatocystin, tobacco tar neutral fraction, and Trp-P1 from cultured broths and cell extracts of 160 strains of bacteria, including about 60 aerobes with the rest being mostly anaerobic intestinal bacteria. Desmutagenic activity was assayed by the Recassay reported by Kada et al. ${ }^{31}$ using spores of the recombination-deficient strain M45 of Bacillus subtilis. A certain amount of mutagen, which caused a 5 to $10 \mathrm{~mm}$ growth inhibition zone around the paper disc with strain M45 and no inhibition zone with its wild type, H15, was incubated with cultured broth or cell extract at $37^{\circ} \mathrm{C}$ for $1 \mathrm{hr}$. The mutagenicity after incubation was checked by the spore Rec-assay. When the sample contained desmutagenic activity, the growth inhibition zone diminished or decreased. Eight strains out of 62,105 out of 162,5 out of 62 , and 83 out of 100 possessed desmutagenic activity against sterigmatocystin, MMC, tobacco tar neutral fraction, and Trp-P1, respectively. But the desmutagenic activity except for MMC was rather weak and not further studied. We focused on the desmutagenic factor against MMC, because such a factor may be applicable for the suppressor of the side-effects of this highly toxic anticancer agent. Among effective strains obtained, we chose Pseudomonas convexa 4-87 to investigate because of its strong desmutagenic activity in the cell extract. The difference of growth inhibition zones with strains M45 and H15 was decreased after treating with MMC of several doses and with this cell extract, confirming the existence of desmutagenic activity. So, only experiments with strain M45 were done for the investigation of the activity hereafter.

Cells were obtained by cultivating $P$. convexa 4-87 at $37^{\circ} \mathrm{C}$ for $20 \mathrm{hr}$ in bouillon supplemented with $1 \%$ glucose $(\mathrm{w} / \mathrm{v})$. The cell extract was prepared by disrupting cells with sonic oscillation. Desmutagenic activity was recovered in the supernatant fraction of ultracentrifugation $(100,200 \times g$ for $1 \mathrm{hr})$. To investigate its activity, the following experiments were done as described in the legends of Table I. After treatment, $60 \mu \mathrm{l}$ of the sample was mixed with $10 \mathrm{ng}$ of $\mathrm{MMC}$ in $5 \mu \mathrm{l}$ of dimethylsulfoxide (DMSO), incubated at $37^{\circ} \mathrm{C}$ for $1 \mathrm{hr}$, transferred onto a paper disc, and the mutagenicity was checked by measuring the growth inhibition zone with strain M45 (Table I). The activity was lost by heat treatment and Pronase P digestion. The activity was also lost by dialysis against deionized water but was regained by the addition of $\mathrm{NAD}(\mathrm{P}) \mathrm{H}$; the effect of $\mathrm{NAD}(\mathrm{P}) \mathrm{H}$ was enhanced by $\mathrm{Ca}^{2+}$ and $\mathrm{Mg}^{2+}$, but not by $\mathrm{Zn}^{2+}, \mathrm{Fe}^{2+}, \mathrm{Cu}^{2+}$, or $\mathrm{Mn}^{2+}$. These results suggest that the desmutagenic factor against $\mathrm{MMC}$ in the cell extract of $P$. convexa 4-87 was proteinous and

TABle I. EFFEcts of Treatments ON THE DESMUTAGENIC ACTIVITY of $P$. convexa $4-87$

\begin{tabular}{ll}
\hline Treatment & $\begin{array}{c}\text { Inhibition zone } \\
(\mathrm{mm})\end{array}$ \\
\hline a) to strain M45 \\
b) No treatment & 6.1 \\
c) Heat treated & 0 \\
d) Pronase P treated & 6.0 \\
e) Dialyzate & 6.1 \\
f) Dialyzate + NADH & 6.1 \\
f) Dialyzate + NADPH & 1.0 \\
g) Dialyzate + NADH $+\mathrm{Ca}^{2+}$ & 1.0 \\
g) Dialyzate + NADH $+\mathrm{Mg}^{2+}$ & 0 \\
g) Dialyzate + NADH $+\mathrm{Zn}^{2+}$ & 5.8 \\
g) Dialyzate + NADH $+\mathrm{Fe}^{2+}$ & 5.0 \\
g) Dialyzate + $\mathrm{NADH}+\mathrm{Ca}^{2+}$ & 6.0 \\
g) Dialyzate + $\mathrm{NADH}+\mathrm{Mn}^{2+}$ & 3.0 \\
\hline
\end{tabular}

a) Ten ng of MMC in $5 \mu$ lof DMSO was mixed with $60 \mu \mathrm{l}$ of $50 \mathrm{~mm}$ Tris buffer ( $\mathrm{pH}$ 7.0).

b) Supernatant fraction of ultracentrifugation of cell extract.

c) Heated in boiling water for $5 \mathrm{~min}$, precipitate removed by centrifugation.

d) Pronase $\mathrm{P}(750,000$ tyrosine units $/ \mathrm{g})$ was added to the concentration of $100 \mu \mathrm{g} / \mathrm{ml}$ and treated at $37^{\circ} \mathrm{C}$ for $30 \mathrm{~min}$.

e) Dialyzed thoroughly against deionized water.

f) $\mathrm{NAD}(\mathrm{P}) \mathrm{H}$ was added to dialyzate to $200 \mu \mathrm{g} / \mathrm{ml}$.

g) Metal ion was added to $5 \mathrm{~mm}$. 
required $\mathrm{NAD}(\mathrm{P}) \mathrm{H}$ for activity. By ammonium sulfate precipitation, activity was recovered between the 40 to $60 \%$ saturated fraction.

According to the results of gel filtration, desmutagenic activity was in two fractions. The major fraction, eluted from the column more slowly, was named fraction I and the minor one, which eluted faster, was named fraction II. We tried to purify both fractions I and II by column chromatography as usual, but complete purification was unsuccessful, because one minor band was observed on disc gel electrophoresis.

Some properties were investigated using the two partially purified fractions obtained above. Molecular weight estimation of the major fraction I was done by gel filtration. According to its elution volume, the molecular weight was estimated as 27,000 28,000. Requirements for cofactors were investigated by the Rec-assay and spectrophotometric assay. We found that both major fraction I and minor fraction II required a reduced form pyridinedinucleotide, NAD(P)H, for the expression of their activity in the Rec-assay. The results of the spectrophotometric assay coincided with the above only for fraction I; the decrease in absorbance at $340 \mathrm{~nm}$ was observed only when fraction $\mathrm{I}, \mathrm{MMC}$, and $\mathrm{NAD}(\mathrm{P}) \mathrm{H}$ were incubated together, but with fraction II, no absorbance change was observed even when $\mathrm{Ca}^{2+}$ and $\mathrm{Mg}^{2+}$ were added to the concentration of $2 \mathrm{~mm}$, although preliminary experiments had shown their effect on the desmutagenic activity of $P$. convexa 4-87. This decrease in absorbance seems mainly dependent on the oxidation of $\mathrm{NAD}(\mathrm{P}) \mathrm{H}$ because at this wavelength, its molecular extinction coefficient is much larger than that of MMC. It is not clear why fraction II did not show the decrease in absorbance at $340 \mathrm{~nm}$ although it showed desmutagenic activity in the Rec-assay only when $\mathrm{NAD}(\mathrm{P}) \mathrm{H}$ was added to the incubation mixture. It may require another factor to express desmutagenic acivity.

Kada et al. reported that the desmutagenic factor discovered in cabbage juice was a peroxidase with NADPHoxidase activity. But the factor did not lose activity through dialysis against a buffer, indicating that cofactor is not directly involved in inactivating mutagenicity. ${ }^{2)}$ So the factor we discovered, for which NAD(P)H is essential for activity, differs from that Kada et al. reported.

The fact that fraction I requires NAD(P)H suggests that a reductive reaction happened with $\mathrm{MMC}$. The mode of action for fraction $\mathrm{I}$ and how the mutagenicity of $\mathrm{MMC}$ was suppressed will be published elsewhere.

Acknowledgments. The authors thank the late Dr. Tsuneo Kada of National Institute of Genetics, Mishima, Japan for his many helpful discussions and encouragement. This work was supported in part by a grant from the Foundation for the Promotion of Research on Medicinal Research.

\section{REFERENCES}

1) T. Osawa, H. Ishibashi, M. Namiki and T. Kada, Biochem. Biophys. Res. Commun., 95, 835 (1980).

2) K. Morita, M. Hara and T. Kada, Agric. Biol. Chem., 42, 1235 (1978); T. Inoue, K. Morita and T. Kada, Agric. Biol. Chem., 45, 345 (1981).

3) K. Hirano, T. Hagiwara, Y. Ohta, H. Matsumoto. and T. Kada, Mutation Res., 97, 339 (1982). 